\title{
The Effect of Islamic Belief and Spiritual Well-being on Organ Donation in Turkey: A Descriptive-Relational Study
}

\author{
Filiz $\operatorname{Taş}^{1} \mathbb{D} \cdot$ Alime Selçuk Tosun ${ }^{2} \mathbb{D} \cdot$ Nurcan Akgül Gündoğdu ${ }^{3}$
}

Accepted: 29 March 2021 / Published online: 17 April 2021

(C) The Author(s), under exclusive licence to Springer Science+Business Media, LLC, part of Springer Nature 2021

\begin{abstract}
The aim of the study is to determine how Islamic belief and spiritual well-being affect the attitudes of individuals towards organ donation. The study was designed as a descriptive-relational study and included the participation of 402 adults in the eastern Mediterranean region of Turkey. For data collection, a personal information form, the Organ Donation Attitude Scale, and the Spiritual Well-being Scale were used. A statistically significant relationship was observed between the acceptance of organ donation according to Islamic beliefs and organ donation attitude. A negative relationship was found between organ donation attitude and the scores on the anomie sub-dimension of the Spiritual Well-being Scale, while a positive relationship was found between organ donation attitude and the scores on the transcendence and harmony with nature sub-dimensions. It was concluded from the results that Islamic belief and spiritual well-being have an effect on the organ donation attitudes of individuals.
\end{abstract}

Keywords Islamic belief · Organ donation attitude $\cdot$ Spiritual well-being

\section{Introduction}

With the developments in medicine, the transplantation of many tissues and organs, including kidney, heart, liver, lung, pancreas, blood, heart valve, cornea, bone marrow, and skin, can be performed more easily today (Marinho et al., 2018; Şantaş and

Filiz Taş

filiztas46@gmail.com

1 Department of Public Health Nursing, Faculty of Health Science, Kahramanmaraş Sütçü Imam University, Kahramanmaraş, Turkey

2 Department of Public Health Nursing, Faculty of Nursing, University of Selcuk, Konya, Turkey

3 Department of Public Health Nursing, Faculty of Health Science, University of Bandırma

Onyedi Eylul, Bandırma, Balıkesir, Turkey 
Şantaş, 2018). These transplantation procedures have been shown to significantly improve quality of life in terms of their impact on physical and emotional life, social relationships and professional development (Can, 2017). Despite the rapid development of the surgical techniques used to perform organ transplantations, the number of transplants able to be performed remains low due to the shortage of organ donations (Müller et al., 2020; Can, 2017; Durur and Akbulut, 2017; Yakıt \& Şen, 2017). Organ Tissue Transplant and Dialysis Services Department according to 2019 data Presidency ready to initiate this process in Turkey; there are 22,868 patients awaiting kidney transplantation, 1,116 awaiting heart transplantation, 2,250 awaiting liver transplantation, and 82 awaiting lung transplantation (https://organ.saglik.gov.tr/ web).

Organ transplants can be performed with organs from those who are living or from those who are newly deceased. In developed countries, most organ requirements are provided by cadaver donors. Yet, in developing countries like Turkey the number of organ transplants able to be performed from cadavers is not sufficient (Domagala et al., 2019; Şantaş and Şantaş, 2018). This situation makes it difficult to meet the organ needs of patients awaiting transplantation and increases the waiting period for organ transplantation (Molina-Pérez et al., 2019). In most cases, the organs to be used in organ transplantation are provided by live organ donation of the relatives of the patient (Molina-Pérez et al., 2019; Goldaracena et al., 2020; Domagala et al., 2019). Studies involving samples of different groups (e.g., hospital staff, students, healthcare professionals, nurses, and teachers) have reported that the reluctance to donate organs is due to lack of knowledge on the subject (Savaşer et al., 2012; Whisenant and Woodring, 2012; Sharma, 2019; Soğukpınar et al., 2019; Yılmaz and Demirağ, 2019). It is therefore clearly important that the public is provided with reliable information about organ donation to secure greater participation in organ donation programs and thereby increase the shortages of organ donations. More studies, however, need to be conducted to determine the factors contributing to reluctance to donate organs. In the literature on this subject, individuals' attitudes towards organ donation are shown to vary according to socio-economic (Başal, 2015; Can, 2017), psycho-social (Ríos et al., 2018) personal, and religious-cultural (Ríos et al., 2018; Uzuntarla, 2019) factors.

As spirituality and religious beliefs affect the way people view life and are responsible for shaping the underlying feelings and thoughts driving many behaviours, they have a major impact on decisions regarding organ donation (Ozbolat, 2017; Berzelak et al., 2019; Uzuntarla, 2019). In addition to spirituality and religious believes, cultural norms also play an important role in the perspective individuals have on death and in turn, their feelings about organ donation. The most widely held religious belief behind organ donation refusal is the belief that bodily integrity must be preserved for life after death (Can, 2017; Tarabeih et al., 2020).

A person's spiritual health guides their spiritual feelings in decisions and is an important factor in terms of establishing a balance between one's beliefs and values and their relationships with themselves and their environment (Hall, 2013). Spiritual health has been shown to correspond to a high level of spiritual well-being (Carey et al., 2011; Ekşi and Kardaş, 2017; Phenwan et al., 2019), which suggests that the relationship between spiritual health and physical health affects the self-esteem of 
individuals and enables individuals to have a positive outlook on life through the positive relationships they are able to establish with those around them (Chirico, 2016; Phenwan et al., 2019). Therefore, individuals who are spiritually healthy are able to establish a strong positive connection with other people and their environment, derive meaning from their lives through their devotion to a divine power and have self-awareness about any negative feelings and thoughts they have about life experiences (Chirico, 2016; Ekşi and Kardaş, 2017). Studies conducted with different groups, such as palliative care patients, patients scheduled to undergo open heart surgery, and cancer patients, have found that individuals with high spiritual wellbeing have high levels of coping skills (Nakagawa et al., 2018; Sun et al., 2016; Paiva et al., 2015; Phenwan et al., 2019).

In addition to the physical, emotional, and social dimensions of the holistic care approach applied by nurses in community health, the spiritual dimension should also be included as a key dimension. (Ergül, 2010; Çınar and Eti-Aslan, 2017). In terms of organ donation, nurses and other healthcare professionals, therefore, should evaluate the spiritual well-being level of individuals to determine the degree to which spirituality and religious beliefs inform the decision-making about organ donation. In this context, the results of the present study will contribute important data to the literature on organ donation decision making, as it is the first study to examine the effects of spiritual well-being and religious belief on organ donation attitude.

The aim of the study, as mentioned just above, is to determine the relationship between organ donation attitudes and spiritual well-being in individuals according to Islamic belief and to identify the variables involved in this relationship.

Research questions

- Is there a statistically significant difference between individuals' sociodemographic characteristics and their organ donation attitude and spiritual well-being?

- Is there a statistically significant difference between individuals' thoughts about organ donation and their attitude to donation and their level of spiritual wellbeing?

- Is there a statistically significant difference between the acceptance of organ donation according to Islamic belief and individuals' organ donation attitude and spiritual well-being?

- What is the relationship between individuals' organ donation attitudes and their spiritual well-being?

\section{Materials and Methods}

\section{Study Design}

This study was designed as a descriptive-relational study. The study sample included 18-65- year-old individuals from Kahramanmaraş, a province in the eastern Mediterranean region of Turkey. The data were collected using a questionnaire that was sent to individuals online due to the ongoing COVID-19 pandemic. In the study, individuals were reached by using the snowball sampling method. An informed consent 
form explaining the purpose of the study was sent and required to be completed before filling out the questionnaires. The research data were collected between July and August of 2020.

\section{Participants and Procedures}

A power analysis was performed to determine the sample size. At a $95 \%$ confidence level and a 5\% margin of error, the minimum sample size was determined to be 369 individuals. A total of 412 individuals were reached within the scope of the research, but 10 individuals were excluded from the study due to failure to state their religious beliefs or to fill out the forms completely. The research was completed with a total of 402 individuals.

The average age of the study participants was $33.06 \pm 10.25$, and $59.5 \%$ were female, $65.2 \%$ were undergraduates, $55.2 \%$ were married, and $54.0 \%$ had a medium income level. Furthermore, $91.3 \%$ of the participants stated that they had never donated organs, $8.7 \%$ had donated organs before, $57.2 \%$ had considered donating their organs, $36.8 \%$ were indecisive about organ donation, and $6.0 \%$ had not given thought about donating their organs. An immediate family member or relative of $76.4 \%$ of the participants had not had an organ transplant, $83.8 \%$ stated that they would accept organ transplantation in case of need, $83.8 \%$ believed that organ donation was suitable according to the religion of Islam, with $16.2 \%$ believing otherwise, and finally, $69.9 \%$ of the participants had never received any information on organ donation.

\section{Ethical Considerations}

Ethical approval to perform the study was granted by the Ethics Committee of Sütçü Imam University, Health and Application Hospital, Faculty of Medicine, Non-clinical Applications (No:2020/12-05). All prospective candidates for the study were required to read and digitally sign an informed consent form that specified the purpose of the study and confirmed that participation in the study was voluntary. This form was added to the beginning of the set of data collection tools.

\section{Data Collection Tools}

A "personal information form", the "Organ Donation Attitude Scale", and the "Spiritual Well-Being Scale (SIOO)" were all used to collect the data.

\section{Personal Information Form}

This form was prepared by the researchers based on the relevant literature (Şantaş and Şantaş, 2018; Can, 2017; Molina-Pérez et al., 2019; Başal, 2015; Ozbolat, 2017; Türky1lmaz et al., 2013). The form included a total of 24 questions, five of which addressed the participants' sociodemographic (e.g., age, gender, marital status, etc.) characteristics, and the remaining 19 addressing the participants' opinions on organ 
donation according to their Islamic belief (e.g., Do you find organ donation do be appropriate in your religion? What are your reasons for accepting the idea of organ donation? What are your reasons for not accepting the idea of organ donation? Are you considering donating organs?)

\section{Organ Donation Attitude Scale}

The Organ Donation Attitude Scale was developed by Parisi and Kanz (1986), and the Turkish reliability and validity study of the scale was conducted by Sayin (2016). Each item of the scale is measured according to a 6-point Likert-type format, with response options ranging between "totally agree" and "totally disagree". The scale consists of 40 items and two sub-dimensions, with the first dimension including 20 items with positive statements related to the "benevolence and moral values / beliefs" about organ donation, and the second dimension including 20 items related to two negative statements, the "fear of medical neglect" and the "fear of bodily injury". The total score is calculated by tallying the points of all items. The lowest possible points for positive attitude were 20 and the highest, 120. Possible scores for the second dimension related to "fear of medical neglect" and "fear of bodily injury" range between 10-60. High positive attitude scores and low negative attitude scores indicate that organ donation attitudes are positive. Cronbach's alpha value of the Turkish version of the scale was reported to be 0.75 (Sayın 2016).

\section{Spiritual Well-Being Scale (SIOÖ)}

This scale, developed by Ekşi and Kardaş, (2017), is a 5-point Likert-type, with response options ranging from $1=$ Does not suit me at all to $5=$ Completely suitable for me. The scale includes three sub-dimensions, "Transcendence", "Harmony with nature" and "Anomie". The Anomie sub-dimension is reversed scored, and the highest possible score obtainable from the total scale is 145 . Higher scores indicate higher level of spiritual well-being. Cronbach's alpha value of the scale was reported to be 0.88. (Ekşi and Kardaş, 2017).

\section{Data analysis}

Data were analysed using the statistical package for the social sciences (SPSS) software. Number (n), percentage (\%), mean (standard deviation), and minimum and maximum values were calculated to provide summary statistics. The normal distribution of the data was evaluated using the Kolmogorov Smirnov test and Q-Q graph, and in cases where the data were not normally distributed, the Mann Whitney-U test and Kruskal-Wallis tests were applied. Spearman correlation analysis was used to 
identify the relationship between different variables. A $p<0.05$ value was considered statistically significant in all analyses.

\section{Findings}

Table 1 presents the distribution of the Participants' opinions on organ donation. The most expressed positive opinion on organ donation was that it would serve to heal another person, with $92.3 \%$ of the participants reporting this opinion, followed by the opinion that they or a relative could become an organ recipient in the future, with $55.7 \%$ of the participants expressing this, and the opinion that they would feel a sense of happiness after agreeing to organ donation, with $27.1 \%$ having this opinion.

Table 1 Participants' opinions on organ donation $(n=402)$

Opinions*

\section{Positive Thoughts}

Organ donation helps someone else to recover

It is possible that $\mathrm{I}$ or a relative will be an organ recipient in the future

Feeling of happiness after organ donation

Belief that a part of a person continues to live after they die

Belief that organ donation would garner respect from society

Negative Thoughts

Lack of confidence in the brain death criteria

Do not want any intervention on the body after dying

In an emergency, if there is an organ donation card, my treatment could be incomplete or $\quad 42 \quad 10.4$ death could be facilitated

My family would not allow organ donation

Organ donation can be used commercially

Reluctance to take responsibility

Opinions of those who consider organ donation suitable according to Islamic belief $*_{n}: 337$

It is a great honour to save lives according to my religious belief

Presidency of Religious Affairs Directorate's fatwa states that organ donation is permissible $94 \quad 23.4$ on religious grounds

By being an organ donor, I would be participating in any good deeds that the person who 33 took my organ would do

Opinions of those who do not consider organ donation suitable according to Islamic belief *n:65

Unsure whether there is a clear provision regarding organ donation in the Quran

Unsure whether there is an explanation on organ donation from the hadiths of the Prophet

The possibility that I would be held responsible for the sins committed by the person who $\quad 5 \quad \begin{array}{lll}5 & 1.2\end{array}$ took my organ

I do not want to be resurrected with a missing organ, as I believe that I will be resurrected 5 after death

*More than one option has been marked. 
The top three negative opinions were lack of confidence in the criteria used to judge a person brain dead, with $12.4 \%$ of the participants expressing this opinion, unwillingness to have any interventions performed on the body, with $11.2 \%$ having this opinion, and fear that if they were to have an organ donation card on them in an emergency, their treatment would be incomplete or death could be facilitated, with $10.4 \%$ having this opinion.

Those who found organ donation to be suitable according to Islamic belief (78.1\%) felt that "being a means to saving lives is a great reward according to their religious belief". Those who did not consider organ donation to be suitable according to the Islamic belief (13.4\%) were "unsure whether there was a clear provision regarding organ donation in the Quran".

In table 2, the participants' mean scores on the organ donation attitude scale the spiritual well-being scale and the related cronbach alpha values shows that the highest mean score was on the "Positive attitude" sub-dimension of the Organ Donation Attitude Scale $(94.36 \pm 18.66)$, while the lowest mean total score was on the "Negative attitude sub-dimension" (50.65 \pm 19.83$)$. On the "Spiritual Well-being Scale" the total "Spiritual Well-being" score was 125.02 \pm 13.88 . Cronbach's alpha values were 0.91 for the Positive Attitude sub-dimension of the Organ Donation Attitude Scale and 0.89 for the total Negative Attitude sub-dimension. The Cronbach's alpha value for the total Spiritual Well-being Scale was 0.90 .

Table 3, the participants' sociodemographic characteristics and analysis results of their opinions on organ donation according to the organ donation attitude scale, shows that there were statistically significant differences in the scores obtained on the Positive Attitude sub-dimension of the Organ Donation Attitude Scale according to gender, organ transplant status in the family, approving of organ donation

Table 2 Participants' Organ donation attitude scale and spiritual well-being scale mean scores and related Cronbach's Alpha values

\begin{tabular}{lccc}
\hline Scales & $\overline{\mathrm{X}} \pm \mathrm{Ss}$ & Min-max & $\begin{array}{c}\text { Cronbach's } \\
\text { Alpha }(\alpha)\end{array}$ \\
\hline $\begin{array}{l}\text { Organ donation attitude scale } \\
\text { Positive attitude }\end{array}$ & & & \\
$\quad$ Benevolence and moral values/beliefs sub- & $94.36 \pm 18.66$ & $20-120$ & 0.91 \\
$\quad$ dimension & & & \\
Negative attitude & $25.12 \pm 10.87$ & $10-60$ & 0.84 \\
Fear of medical neglect sub-dimension & $25.52 \pm 10.37$ & $10-60$ & 0.82 \\
Fear of bodily injury sub-dimension & $50.65 \pm 19.83$ & $20-120$ & 0.89 \\
Negative attitude total & & & 0.92 \\
Spiritual well-being scale & $67.22 \pm 9.04$ & $15-75$ & 0.78 \\
Transcendence sub-dimension & $32.14 \pm 3.34$ & $7-35$ & 0.83 \\
Harmony with nature sub-dimension & $25.65 \pm 5.90$ & $7-35$ & 0.90 \\
Anomie sub-dimension & $125.02 \pm 13.88$ & $29-145$ & \\
Spiritual Well-being Total & & & \\
\hline
\end{tabular}




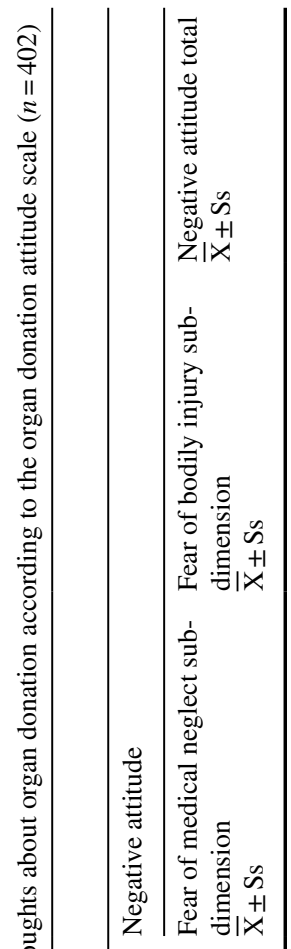

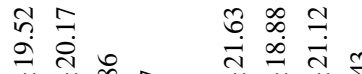

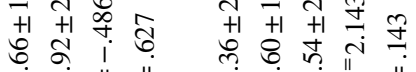

กิ กิ

$=\stackrel{\infty}{a} \infty$

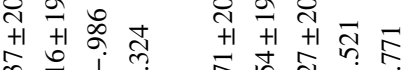

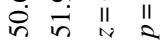

in

के ने ॥

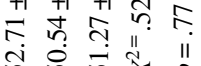

$\because \stackrel{2}{2}$

ప. กे

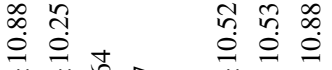

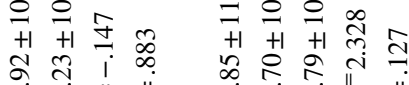

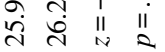

ते ปู่

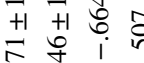

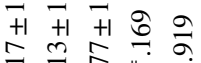

तें⿰⿺乚一匕

पे त़

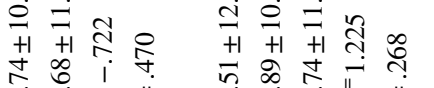

$\therefore 8$

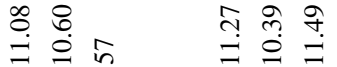

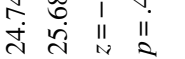

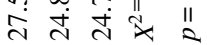

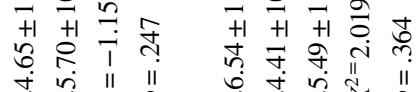

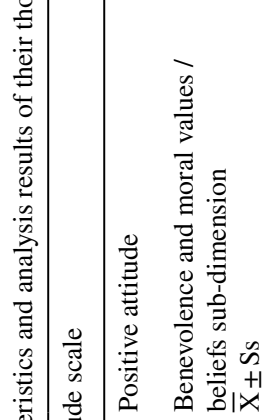

กิ้

ते

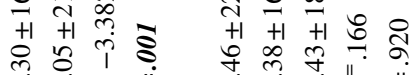

$\infty n$

กิ

๙ิ

๙ूँ

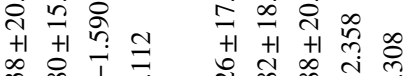

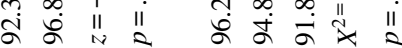

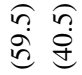

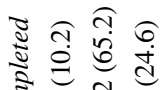

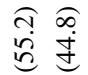

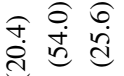

ते है

‡

สิ

등

范

ฐ)

ร

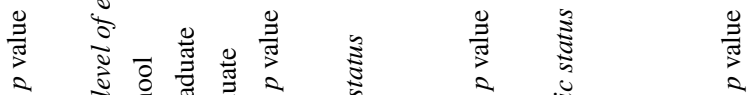

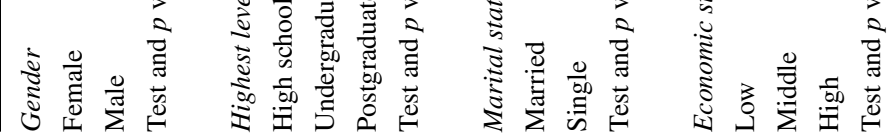




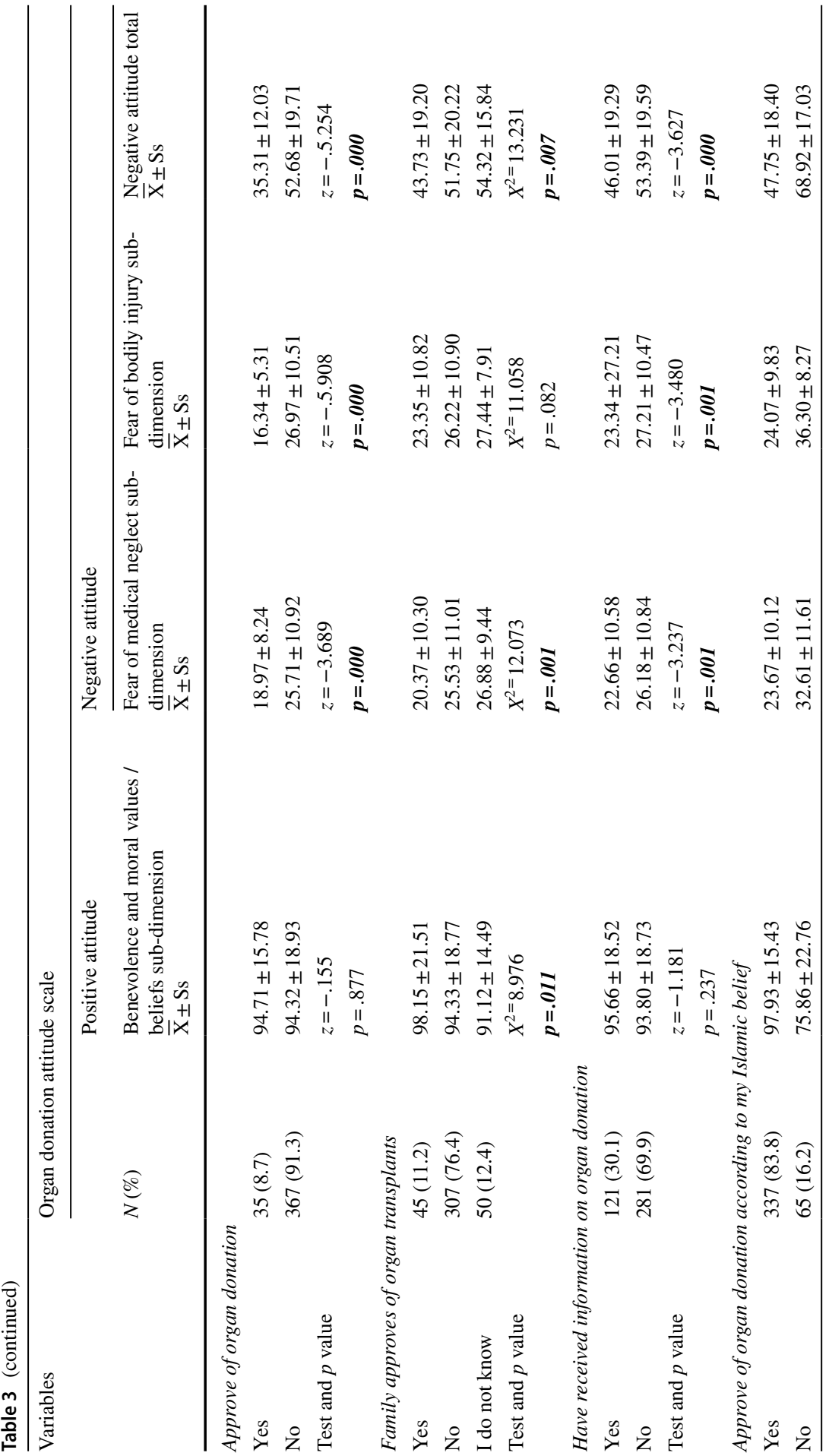




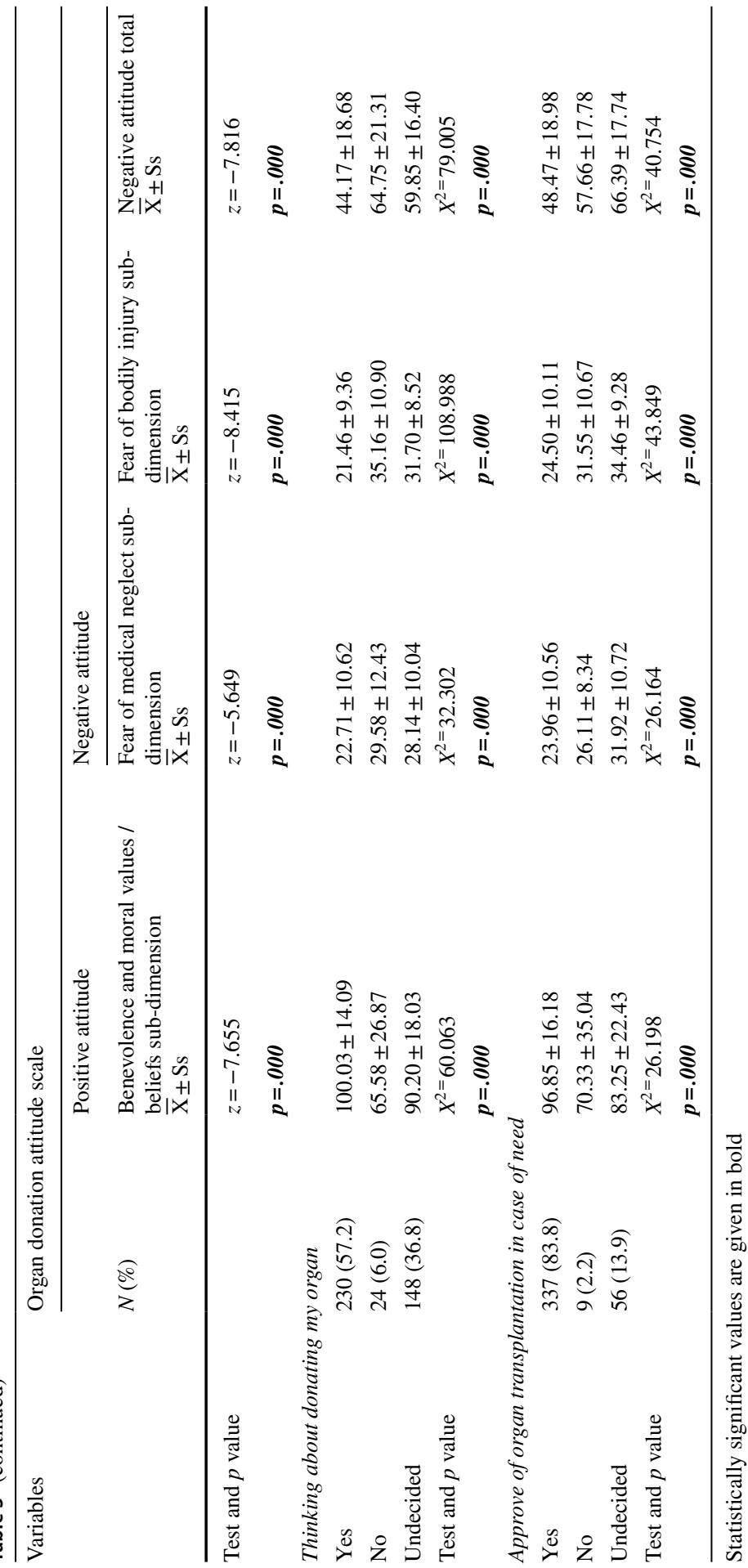


according to Islamic belief, thinking about donating an organ, and accepting organ transplantation in cases of need $(p<0.05)$.

Statistically significant differences were also found in the scores obtained on the Negative Attitude sub-dimension of the Organ Donation Attitude Scale according to organ donation status, organ transplant status in the family, status of having received information about organ donation, approving of organ donation according to Islamic belief, thinking about donating an organ, and accepting organ transplantation in cases of need $(p<0.05)$.

No statistically significant difference was found in terms of scores on the Positive Attitude sub-dimension of the Organ Donation Attitude Scale and the participants' education, marital status, economic status, organ donation attitude, and status of having received information on organ donation $(p>0.05)$.

Table 4, which presents the participants' socio-demographic characteristics and analysis results of their opinions on organ donation according to the Spiritual Well-being Scale sub-dimension and total scores, shows that there were statistically significant differences on the Transcendence sub-dimension scores according to gender, marital status, and acceptance of organ transplantation in cases of need $(p<0.05)$. Statistically significant differences were also found between scores on the Spiritual Well-being sub-dimension of Harmony with Nature" and accepting organ transplantation, gender, and acceptance of organ transplantation in cases of need $(p<0.05)$. Statistically significant differences were observed between scores on the Anomie sub-dimension of the Spiritual Well-being Scale and education, marital status, economic status, organ donation, status on having received information about organ donation, thinking about donating an organ, and accepting organ transplantation in cases of need $(p<0.05)$. Finally, a statistically significant difference was found between the total Spiritual well-being scores of the Spiritual Well-being Scale and accepting organ transplantation in cases of need and marital status $(p<0.05)$.

Table 5, which presents the correlation between organ donation attitude and spiritual well-being, shows that there was a significant inverse relationship between the participants' positive attitude to organ donation and anomie $\left(r=-.125^{*} ; p=0.05\right)$.

There was a significant positive correlation between "positive organ donation attitude" and "transcendence" ( $\left.r=.145^{* *} ; p=0.01\right)$ and "harmony with nature" $(r=$ $\left..257^{* *} ; p=0.01\right)$.

A statistically significant inverse correlation was found between negative organ donation attitude and harmony with nature $(r=-.182 * * ; p=0.01)$, anomie $(r=-.228 * * ; p=0.01)$, and Total spiritual well-being $\left(r=-.153^{* *} ; p=0.01\right)$.

\section{Discussion}

One of the most important issues related to organ transplantation in Turkey is insufficient organ donations. Barriers to organ transplantation and donation are universal. With this study being the first to examine the effect of religious beliefs and spiritual well-being on the organ donation attitudes of adults, the results obtained will contribute valuable information to the literature on this subject. 
Table 4 Participants' sociodemographic characteristics and analysis results of their thoughts about organ donation according to spiritual well-being sub-dimensions and total scores $(n=402)$

\begin{tabular}{lll}
\hline Variables & & \multicolumn{2}{l}{ Spiritual well-b } \\
\cline { 3 - 3 } & $N(\%)$ & TranscendenceX \\
& & \\
\hline Gender & & \\
Female & $239(59.5)$ & $68.09 \pm 8.43$ \\
Male & $163(40.5)$ & $65.94 \pm 9.74$ \\
Test and $p$ value & & $z=-2.363$ \\
& & $p=.018$
\end{tabular}

Highest level of education completed

\begin{tabular}{|c|c|c|c|c|c|}
\hline High school & $41(10.2)$ & $69.48 \pm 5.97$ & $32.56 \pm 2.68$ & $25.53 \pm 6.17$ & $127.58 \pm 11.62$ \\
\hline Undergraduate & $262(65.2)$ & $67.06 \pm 9.05$ & $32.22 \pm 3.17$ & $25.15 \pm 6.05$ & $124.45 \pm 13.75$ \\
\hline Postgraduate & $99(24.6)$ & $66.70 \pm 9.94$ & $31.76 \pm 3.98$ & $27.01 \pm 5.17$ & $125.48 \pm 15.01$ \\
\hline \multirow[t]{2}{*}{ Test and $p$ value } & & $X^{2}=.859$ & $X^{2}=.697$ & $X^{2}=6.305$ & $X^{2}=2.046$ \\
\hline & & $p=.651$ & $p=.706$ & $p=.043$ & $p=.360$ \\
\hline \multicolumn{6}{|l|}{ Marital status } \\
\hline Married & $222(55.2)$ & $68.17 \pm 8.39$ & $32.00 \pm 3.56$ & $27.13 \pm 4.89$ & $127.31 \pm 12.96$ \\
\hline Single & $180(44.8)$ & $66.05 \pm 9.67$ & $32.33 \pm 3.05$ & $23.82 \pm 6.51$ & $122.20 \pm 14.48$ \\
\hline \multirow[t]{2}{*}{ Test and $p$ value } & & $z=-2.430$ & $z=-.354$ & $z=-5.211$ & $z=-3.752$ \\
\hline & & $p=.015$ & $p=.723$ & $p=.000$ & $p=.000$ \\
\hline \multicolumn{6}{|l|}{ Economic status } \\
\hline Low & $82(20.4)$ & $66.74 \pm 10.52$ & $32.17 \pm 3.34$ & $23.76 \pm 6.11$ & $122.68 \pm 14.28$ \\
\hline Middle & $217(54.0)$ & $66.99 \pm 8.88$ & $32.20 \pm 3.15$ & $25.56 \pm 6.05$ & $124.76 \pm 14.18$ \\
\hline High & $103(25.6)$ & $68.08 \pm 8.05$ & $32.00 \pm 3.75$ & $27.33 \pm 4.88$ & $127.43 \pm 12.61$ \\
\hline \multirow[t]{2}{*}{ Test and $p$ value } & & $X^{2}=.434$ & $X^{2}=.007$ & $X^{2}=15.108$ & $X^{2}=4.767$ \\
\hline & & $p=.805$ & $p=.997$ & $p=.001$ & $p=.092$ \\
\hline \multicolumn{6}{|c|}{ Approve of organ donation } \\
\hline Yes & $35(8.7)$ & $63.71 \pm 12.91$ & $31.82 \pm 3.69$ & $27.68 \pm 4.23$ & $123.22 \pm 17.55$ \\
\hline No & $367(91.3)$ & $67.55 \pm 8.52$ & $32.17 \pm 3.31$ & $25.45 \pm 6.00$ & $125.19 \pm 13.49$ \\
\hline \multirow[t]{2}{*}{ Test and $p$ value } & & $z=-.453$ & $z=-.489$ & $z=-2.031$ & $z=-.003$ \\
\hline & & $p=.651$ & $p=.625$ & $p=.042$ & $p=.998$ \\
\hline \multicolumn{6}{|c|}{ Family approves of organ transplants } \\
\hline Yes & $45(11.2)$ & $66.64 \pm 11.85$ & $32.37 \pm 3.99$ & $26.28 \pm 5.96$ & $125.31 \pm 16.28$ \\
\hline No & $307(76.4)$ & $67.55 \pm 8.49$ & $32.31 \pm 3.05$ & $25.78 \pm 5.84$ & $125.65 \pm 13.02$ \\
\hline I do not know & $50(12.4)$ & $65.70 \pm 9.41$ & $30.94 \pm 4.17$ & $24.28 \pm 6.16$ & $120.92 \pm 16.10$ \\
\hline \multirow[t]{2}{*}{ Test and $p$ value } & & $X^{2}=2.169$ & $X^{2}=4.913$ & $X^{2}=2.473$ & $X^{2}=3.352$ \\
\hline & & $p=.338$ & $p=.086$ & $p=.290$ & $p=.187$ \\
\hline \multicolumn{6}{|c|}{ Received information on organ donation } \\
\hline Yes & $121(30.1)$ & $65.91 \pm 10.19$ & $32.25 \pm 3.11$ & $26.73 \pm 5.75$ & $124.90 \pm 14.51$ \\
\hline No & $281(69.9)$ & $67.78 \pm 8.45$ & $32.10 \pm 3.44$ & $25.18 \pm 5.91$ & $125.07 \pm 13.62$ \\
\hline \multirow[t]{2}{*}{ Test and $p$ value } & & $z=-1.432$ & $z=-.239$ & $z=-2.388$ & $z=-.011$ \\
\hline & & $p=.152$ & $p=.811$ & $p=.017$ & $p=.991$ \\
\hline
\end{tabular}

$\begin{array}{lll}32.87 \pm 2.56 & 25.29 \pm 5.82 & 126.25 \pm 12.56 \\ 31.09 \pm 4.01 & 26.17 \pm 6.00 & 123.21 \pm 15.48 \\ z=-4.770 & z=-1.772 & z=-1.493 \\ p=.000 & p=.076 & p=.135\end{array}$

Harmony with Anomie $\bar{X}_{ \pm}$Ss Spiritual well-being total $\overline{\mathrm{X}} \pm \mathrm{Ss}$ 
Table 4 (continued)

\begin{tabular}{|c|c|c|c|c|c|}
\hline \multirow[t]{2}{*}{ Variables } & \multirow[b]{2}{*}{$N(\%)$} & \multicolumn{4}{|c|}{ Spiritual well-being scale } \\
\hline & & Transcendence $\bar{X} \pm$ Ss & $\begin{array}{l}\text { Harmony with } \\
\text { nature } \bar{X}_{ \pm S s}\end{array}$ & Anomie $\bar{X}_{ \pm}$Ss & $\begin{array}{l}\text { Spiritual } \\
\text { well-being } \\
\text { total' } \pm \text { Ss }\end{array}$ \\
\hline \multicolumn{6}{|c|}{ Approve of organ donation according to my Islamic belief } \\
\hline Yes & $337(83.8)$ & $66.91 \pm 9.37$ & $32.11 \pm 3.34$ & $25.58 \pm 5.82$ & $124.62 \pm 14.02$ \\
\hline No & $65(16.2)$ & $68.80 \pm 6.93$ & $32.30 \pm 3.39$ & $25.98 \pm 6.35$ & $127.09 \pm 13.00$ \\
\hline \multirow[t]{2}{*}{ Test and $p$ value } & & $z=-1.202$ & $z=-.713$ & $z=-.764$ & $z=-1.443$ \\
\hline & & $p=.229$ & $p=.476$ & $p=.445$ & $p=.149$ \\
\hline \multicolumn{6}{|c|}{ Thinking about donating my organ } \\
\hline Yes & $230(57.2)$ & $66.74 \pm 8.98$ & $32.36 \pm 2.93$ & $25.66 \pm 5.87$ & $124.78 \pm 13.84$ \\
\hline No & $24(6.0)$ & $68.16 \pm 7.56$ & $32.33 \pm 3.57$ & $28.50 \pm 5.80$ & $129.00 \pm 13.69$ \\
\hline Undecided & $148(36.8)$ & $67.81 \pm 9.35$ & $31.77 \pm 3.86$ & $25.16 \pm 5.87$ & $124.75 \pm 13.96$ \\
\hline \multirow[t]{2}{*}{ Test and $p$ value } & & $X^{2}=1.546$ & $X^{2}=1.029$ & $X^{2}=7.21$ & $X^{2}=3.16$ \\
\hline & & $p=.462$ & $p=.598$ & $p=.027$ & $p=.205$ \\
\hline \multicolumn{6}{|c|}{ Approve of organ transplantation in case of need } \\
\hline Yes & $337(83.8)$ & $67.28 \pm 8.49$ & $32.30 \pm 3.05$ & $25.79 \pm 5.84$ & $125.38 \pm 13.13$ \\
\hline No & $9(2.2)$ & $73.33 \pm 2.34$ & $33.66 \pm 2.59$ & $29.11 \pm 4.91$ & $136.11 \pm 4.48$ \\
\hline Undecided & $56(13.9)$ & $65.85 \pm 12.09$ & $30.98 \pm 4.64$ & $24.23 \pm 6.17$ & $121.07 \pm 17.66$ \\
\hline \multirow[t]{2}{*}{ Test and $p$ value } & & $X^{2}=8.078$ & $X^{2}=6.084$ & $X^{2}=6.436$ & $X^{2}=10.207$ \\
\hline & & $p=.018$ & $p=.048$ & $p=.040$ & $p=.006$ \\
\hline
\end{tabular}

Statistically significant values are given in bold

Table 5 Correlation between participants' organ donation attitude and spiritual well-being

\begin{tabular}{lllllll}
\hline Variables & 1 & 2 & 3 & 4 & 5 & 6 \\
\hline Positive Attitude & 1 & & & & & \\
Negative Attitude & $-326^{* *}$ & 1 & & & & \\
Transcendence & $.145^{* *}$ & -.056 & 1 & & & \\
Harmony with Nature & $.257^{* *}$ & $-.182^{* *}$ & $.558^{* *}$ & 1 & & \\
Anomie & $-.125^{*}$ & $-.228^{* *}$ & $.294^{* *}$ & $.284^{* *}$ & 1 & \\
Spiritual Well-being Total & .067 & $-.153^{* *}$ & $.816^{* *}$ & $.664^{* *}$ & $.707^{* *}$ & 1 \\
\hline
\end{tabular}

*Correlation is significant at the 0.05 level

**Correlation is significant at the 0.01 level $^{\circ}$ The values on the table represent the value of $\mathrm{r}$.

In the study, the female participants were found to have higher positive attitudes towards organ donation scores $(97.30 \pm 16.26)$ and lower negative attitude scores $(50.66 \pm 19.52)$ than those of the males, with the difference between them being statistically significant $(p<0.05)$.

Similar results were obtained in many studies conducted with both students and adults in Turkey (Başal, 2015; Türky1lmaz et al., 2013; Soysal and Kaya, 2019). The differences seen between regions and between countries in terms of organ donation 
may result from traditions, the scope of religious beliefs, and individual characteristics. These factors have been shown to vary depending on legal systems, and consent procedures (Marinho et al., 2018; Molina-Pérez et al., 2019; Goldaracena et al., 2020).

In this study, there was no statistically significant relationship between the education status of the $30.1 \%$ of the participants who had received information on organ donation and their positive attitude towards organ donation $(p>0.05)$. It was further determined that the negative attitude towards organ donation scores of the educated group were significantly lower statistically than those of others $(p<0.05)$. The majority of the individuals constituting the study group had a university education. Other studies on this subject have highlighted the lack of knowledge and awareness about organ donation and have argued that donation rates can be increased with the help of media, the internet and awareness-raising programs (Ozbolat, 2017; Tarhan et al., 2015; Müller et al., 2020).

In a study by Başal (2015), the importance of media and awareness campaigns aimed at providing information and remedying the fear about organ donation was raised. Panwar et al., (2016) addressed this issue within the framework of the question, "Why do we have low rates of organ donation?", and they found that there was a lack of information / awareness about organ donation. They went on to suggest that donation rates could be increased through the help of media, the internet and awareness-raising programs.

The participants in the present study had a high mean score $(94.36 \pm 18.66)$ on the Positive attitude (benevolence and moral values/ beliefs) sub-dimension and a low mean score $(50.65 \pm 19.83)$ on the Negative attitude (fear of medical neglect and fear of bodily injury) sub-dimension. The fact that the participants had higher scores in the positive sub-dimension and lower scores in the negative sub-dimension indicates that their attitudes towards organ donation were generally positive (Sayın, 2016). In other words, the participants showed a willingness to donate organs. However, only $8.7 \%$ of the participants reported that they had donated organs. The majority of those who had negative attitudes about organ donation did not wish to donate due to "lack of trust in healthcare professionals" ( $n=50 ; 12.4 \%)$.

In examining other studies conducted on the subject, it was found that results similar to those of the present study were obtained. Furthermore, these studies have reported that while the number of people who want to donate is high, the number of people who actually donate organs is low. In comparing the rate of those who were thinking about donating organs and the rates of those who actually do it, it can be observed that there is inconsistency between the knowledge, attitude, and behaviours about organ donation (Ozbolat, 2017; Soysal and Kaya, 2019; Sharma, 2019; Marinho et al., 2018; Başal, 2015; Müller et al., 2020; Molina-Pérez et al., 2019).

The findings from the present study are largely in line with those reported in the literature. It is important to understand why there is a gap between the number of people willing to donate and those who follow the procedures required to donate. The information obtained from this study and from the literature indicates that although individuals have positive attitudes towards organ donation, they cannot transfer this attitude to behaviour, and that this is a universal problem. More indepth studies on the cause of this need to be conducted. 
In this study, it was observed that $83.8 \%$ of the participants found organ donation to be acceptable according to their religion, and their positive attitude scores were higher, and those who found organ transplantation to be acceptable in the eyes of Islam had statistically significantly lower negative attitude scores $(p<0.05)$. Moreover, $78.1 \%$ of those whose approval of organ donation aligned with their Islamic beliefs found it to be right on account of their opinion that it saved lives and was a good deed. The $13.4 \%$ who did not consider organ donation to be suitable according to the religion of Islam expressed that they did not want to donate any of their organs because they were unsure whether there were any explanations about organ donation in the al-Quran. Many of the studies conducted in Turkey have found that religious beliefs have an important place among the reasons individuals refuse organ donation, and that the public does not realize that organ donation and transplantation are suitable in the eyes of Islam (Tarhan et al., 2015; Can, 2017; Türkyılmaz et al., 2013; Soysal and Kaya, 2019).

Ş1pkin et al. (2010), in their study, reported that $85.4 \%$ of those who found organ donation to be religiously acceptable had positive attitudes toward organ donation, and that $70.7 \%$ felt that religious beliefs prevented sufficient organ donation. Türkyılmaz et al. (2013) indicated in their study that $83.3 \%$ of Islamic religious officials, $13.6 \%$ of Christian religious officials, and $7.3 \%$ of Judaic religious officials claim that organ donation is allowed in their respective belief systems. In similar studies conducted in different countries, it was seen that those who think that their religion approves of organ donation view organ donation more positively (Carey et al., 2011; Ríos et al., 2018; Krupic et al., 2016; Tarabeih et al., 2020). In a study conducted by Tarabeih et al. (2020) to explore the differences in views on organ donation between the members of the three monotheistic religions, Christianity, Islam and Judaism, it was determined that the willingness of members of all three religions to donate organs after death was low (Mean responses of Jews, Muslims and Christians were 2.11 $\pm 0.49,2.31 \pm 1.09$, and 2.30 \pm 0.66 , respectively). Tumin et al. (2013), in their study examining the relationship between organ donation rates and religious belief, reported that for a majority of the participants, organ donation was compatible with Islam. Turkey is a developing country, where Islam is dominant. For Muslims, religious beliefs serve as a guide to behaviour and therefore play an important role in determining views on organ transplantation. Islam is a religion that approves organ transplantation, and there are also sayings attributed to the Prophet Muhammad that encourage Muslims to help their fellow human being, such as "Whoever helps another will be granted help from Allah in the Hereafter". There are some verses in the al-Quran that are used to support organ donation, such as "Whoever saves someone else's life, it is as if he saves the life of all humanity". (Holy al-Quran, al-Maide 5-32). (Tarabeih et al., 2020; Soysal and Kaya, 2019; Abdeldayem et al., 2016). It has been suggested that campaigns conveying the positive messages given by the religion of Islam about organ transplantation would make a positive contribution to increasing rates of organ donation (Tarhan et al., 2015; Ozbolat, 2017). The present study findings are consistent with those reported in the literature. Religious beliefs and knowledge on organ donation affect people's attitudes. 
In the study, it was observed that the spiritual well-being level of the participants was high $(125.02 \pm 13.88)$, particularly more so in women, married people, those with high income, those who accepted organ transplantation, and those who had received information about organ donation $(p<0.05)$. Spirituality, which constitutes the essence of a human being, refers to the sense of attachment to the divine and informs understanding of meaning of life, the universe, and God (Phenwan et al., 2019). Spiritual and psycho-social factors are believed to be related to spiritual well-being. Studies involving different topics have produced the similar finding that as spiritual well-being increases, psychological well-being also increases (Bilgiç and Çıtak-Bilgin, 2020).

In this study, there was a significantly negative $\left(r=-.125^{*} ; p=0.05\right)$ correlation between the positive attitudes held by individuals on organ donation and 'anomie'.

Anomie refers to negative thoughts about the meaning and purpose of life. It has been observed that when individuals' negative thoughts decrease, organ donation attitudes become more positive.

In this study, it was determined that there was a significant positive correlation between "positive organ donation attitude" and "transcendence" $\left(r=.145^{* *} ; p=0.01\right)$ and "harmony with nature" $(r=.257 * * ; p=0.01)$.

Transcendence refers to an understanding of life and the process of living through devotion to and relationship with a divine power. Harmony with nature refers to the dependence on and relationship with nature and other living things in nature. The positive correlation between organ donation attitude and transcendence and harmony with nature demonstrates that the participants valued their quality of life and had a love for living things in the universe.

Since there were no similar studies on the relationship between organ donation attitudes and spiritual well-being, this issue cannot be discussed within the framework of comparison. The relationship between positive attitudes on organ donation and spiritual well-being can, however, be explained by the spiritual feelings of individuals (Chirico, 2016; Phenwan et al., 2019).

According to the findings from this study, there was a significant negative correlation between "negative organ donation attitude" and total spiritual well-being $\left(r=-.153^{* *} ; p=0.01\right)$, and the majority of those willing to donate organs were inspired to do so by the idea of "helping a sick person to recover" $(n=371,92.3 \%)$.

Spirituality functions as an internal power within individuals that strengthens them against physical and emotional threats that endanger their integrity and continuity. This study found that the participants with strong spiritual well-being had more positive attitudes towards organ donation. Helping people makes it easier to cope with stress and improves psychological well-being by the positive effects it has on mental health. Spiritual well-being is associated with psychological wellbeing, happiness, and lower stress levels. It has been shown that as spiritual wellbeing increases, the desire to share with people and to help people also increases (Ergül, 2010). 


\section{Limitations and Strengths of the Study}

This study was conducted with adults living in a province in the eastern Mediterranean region of Turkey. Therefore, the results of the study cannot be generalized to the larger population. The main strengths of this study were that it is the first study, nationally and internationally, to examine the relationship between the Islamic-inspired attitudes toward organ donation and spiritual well-being, and that it had a relatively large sample size.

\section{Conclusion}

Overall, this study identified a statistically significant relationship between gender, family organ transplant status, acceptance of organ donation according to Islam, acceptance of organ transplantation in cases of need, and organ donation attitude. A statistically significant negative relationship was identified between positive attitude to organ donation and "anomie", while a statistically significant positive relationship was identified between "transcendence" and "harmony with nature". Furthermore, a statistically significant negative correlation was found between negative attitude to organ donation and total Spiritual well-being.

Although the rate of those who would consider donating organs was high, the rate of individuals who actually donated organs was low. It was concluded that demographic, socio-economic, spiritual, and religious factors have an effect on the willingness of individuals to donate organs,

\section{Implications for Practice}

Although studies conducted in Turkey and throughout the world have indicated there to be sufficient numbers of organ transplant centres and experienced health personnel and physicians, organ donation rates remain far below desired levels, which suggests that there is a mentality structure that underlies the behaviour, attitudes and beliefs towards organ donation. While there are other socio-cultural factors that likely influence the decision-making process in organ donation, it is clear that religion plays an important role in the organ donation decision-making process for individuals. Nurses and healthcare professionals, therefore, need to be aware of the problems individuals face by conducting in-depth interviews with them in order to help them overcome any barriers they may have to organ donation and to arrive at targeted solutions. Healthcare professionals should also of course encourage individuals to donate organs, and in the planning of intervention programs, importance should be attached to spirituality

Religious officials can also play a role in helping individuals to express their feelings about organ donation. For example, they could contribute to alleviating the shortage of organ and tissue donors by meeting with people during the grieving period for the death of their loved ones and friends. 
Targeted strategies must be adopted and implemented to solve the organ donation problem. Religious, cultural and social approaches to organ donation should be used when communicating directly with individuals, families, and communities about organ donation

Acknowledgements We would like to thank all the individuals who participated in this study.

Author Contributions Study concept and design, FT, AST and NAG, Collection of data, analysis of data, FT, AST. Preparation of the article, FT, AST, Study supervision, FT, AST and NAG.

Funding This research received no specific grant from any funding agency in the public, commercial, or not-for-profit sectors.

\section{Declarations}

Conflict of interest The authors declare that they have no financial or nonfinancial conflict of interest with any organization related to the contents of this paper.

Ethical Approval All procedures performed in this study, including data collection from the participants, were in accordance with the 1964 Declaration of Helsinki and its later amendments or comparable ethical standards.

Informed Consent All the research participants were informed about the objectives and procedures of the study. Informed consent was obtained from all individual participants included in the study.

\section{References}

Abdeldayem, H., Farag El-Kased, A., Elshaarawy, A., Hammad, E. S., Al-Haddad, O., Sobhi, G., \& Allam, N. (2016). Religious concepts in organ transplantation. Open access peer-reviewed chapter. https://doi.org/10.5772/62401

Başal, B. (2015). The reasons of low organ donation rates and remedy suggestıons: a field survey. International Journal of Social Science., 33, 207-221. https://doi.org/10.9761/JASSS2849

Berzelak, N., Avsec, D., \& Kamin, T. (2019). Reluctance and willingness for organ donation after death among the slovene general population. Zdravstveno varstvo/Slovenian Journal of Public Health, 58(4), 155-163. https://doi.org/10.2478/sjph-2019-0020

Bilgiç, G., \& Çıtak-Bilgin, N. (2020). Relationship between fear of childbirth and psychological and spiritual well-being in pregnant women. Journal of Religion and Health. https://doi.org/10.1007/ s10943-020-01087-4

Can, F. (2017). A Review on family approval on organ donation. Object Psychology Journal, 5(9), 131149. https://doi.org/10.7816/nesne-05-09-07

Carey, L. B., Robinson, P., \& Cohen, J. (2011). Organ procurement and health care chaplaincy in Australia. Journal of Religion and Health, 50(3), 743-759. https://doi.org/10.1007/s10943-009-9279-1

Chirico, F. (2016). Spiritual well-being in the 21st century: It is time to review the current WHO's health definition. Journal of Health and Social Sciences, 1(1), 11-16. https://doi.org/10.19204/2016/sprt2

Çınar, F., \& Eti-Aslan, F. (2017). Spiritualizm ve hemşirelik: "Yoğun bakım hastalarında spiritüel bakımın önemi" (Spiritualism and nursing: the importance of spiritual care in intensive care patients). Beykent Üniversitesi Jaren Hemşirelik Akademik Araştırma Dergisi, 3(1), 37-42. https:// doi.org/10.5222/jaren.2017.037.(xxxinTurkish)

Domagala, P., Takagi, K., Ijzermansa, J. N., \& Polaka, W. G. (2019). Grafts from selected deceased donors over 80 years old can safely expand the number of liver transplants: A systematic review and meta-analysis. Transplantation Reviews, 33(4), 209-218. https://doi.org/10.1016/j.trre.2019.06.004 
Durur, F., \& Akbulut, Y. (2017). Türkiye'de organ nakline yönelik politikaların değerlendirilmesi, (Evaluation of policies for organ transplantation in Turkey). Business and Management Studies an International Journal, 5(3), 570-585. https://doi.org/10.15295/bmij.v5i3.150

Ekşi, H., \& Kardaş, S. (2017). Spiritual well-being: Scale development and validation. Spiritual Psychology and Counseling, 2(1), 73-88. https://doi.org/10.12738/spc.2017.1.0022

Ergül, Ş. (2010). Hemşirelik eğitiminde maneviyat ve manevi bakım kavramları nerede? Ne zaman? Nasil? (The concepts of spirituality and spiritual care in nursing education where? when? how?) Ege Üniversitesi Hemşirelik Fakültesi Dergisi, 26(1), 65-75. https://dergipark.org.tr/en/download/articlefile/835963 (xxx.InTurkısh).

Goldaracena, J. N., Cullen, M., Dong-Sik, K., Ekser, B., \& Karim, J. H. (2020). Expanding the donor pool for liver transplantation with marginal donors. International Journal of Surgery., 82(Supplement), 30-35. https://doi.org/10.1016/j.ijsu.2020.05.024

Hall, A. M. (2013). Spititual health. In P. A. Potter, A. G. Perry, P. A. Stockert, \& A. M. Hall (Eds.), Fundamentals of Nursing. (pp. 692-704). Elsevier Mosby: Missouri.

https://organ.saglik.gov.tr/web. (Access Date: 04.06.2020)

Krupic, F., Sayed-Noor, A. S., \& Fatahi, N. (2016). The impact of knowledge and religion on organ donation as seen by immigrants in Sweden. Scandinavian Journal Caring Sciences, 31(4), 687-694. https://doi.org/10.1111/scs. 12379

Marinho, B. B. O., Santos, A. T. F., Figueredo, A. S., Cortez, L. S. A. B., Viana, M. C. A., Santos, G. M., et al. (2018). Challenges of organ donation: potential donors for transplantation in an area of Brazil's Northeast. Transplantation Proceedings, 50(3), 698-701. https://doi.org/10.1016/j.transproce ed.2018.02.055

Molina-Pérez, A., David Rodríguez-Arias, D., Delgado-Rodríguez, J., Morgan, M., Frunza, M., Randhawa, G., et al. (2019). Public knowledge and attitudes towards consent policies for organ donation in Europe. A systematic review. Transplantation Reviews, 33(1), 1-8. https://doi.org/10.1016/j.trre. 2018.09.001

Müller, P. C., Kabacam, G., Vibert, E., Germani, G., \& Petrowsky, H. (2020). Current status of liver transplantation in Europe. International Journal of Surgery., 82(Supplement), 22-29. https://doi. org/10.1016/j.ijsu.2020.05.062

Nakagawa, S., Hua, M., \& Takayama, H. (2018). Who is not comfortable with the term "palliative care"patient, family, or surgeon? Journal Thoracic and Cardiovascular Surgery, 155(5), 2032-33. https:// doi.org/10.1016/j.jtcvs.2018.01.004

Ozbolat, A. (2017). "Organlarımla dirilmek istiyorum."- Organ bağışının dini-toplumsal arka planı ("I want to resurge with my organs" religious-social background of organ donation). Çukurova Üniversitesi İlahiyat Fakültesi Dergisi, 17(1), 61-87

Paiva, B. S., Carvalho, A. L., Lucchetti, G., Barroso, E. M., \& Paiva, C. E. (2015). "Oh, yeah, I'm getting closer to god": Spirituality and religiousness of family caregivers of cancer patients undergoing palliative care. Support Care Cancer, 23(8), 2383-89. https://doi.org/10.1007/s00520-015-2604-1

Panwar, R., Sujoy, P., Nihar, R. D., Peush, S., Aarti, V., \& Mahesh, C. M. (2016). Why are we poor organ donors: a survey focusing on at-titudes of the lay public from Northern India. Journal of Clinical and Experimental Hepatology, 6(2), 81-86. https://doi.org/10.1016/j.jceh.2016.04.001

Parisi, N., \& Katz, I. (1986). Attitudes towards posthumous organ donation and commitment to donate. Health Psychology, 5(6), 565-580. https://doi.org/10.1037//0278-6133.5.6.565

Phenwan, T., Peerawong, T., \& Tulathamkij, K. (2019). The meaning of spirituality and spiritual well being among thai breast cancer patients: A qualitative study. Indian Journal of Palliative Care, 25(1), 119-23. https://doi.org/10.4103/IJPC.IJPC_101_18

Ríos, A., López-Navas, A. I., Flores-Medina, J., Sánchez, A., Ayala, M. A., Garrido, G., et al. (2018). Psychosocial factors affecting attitude toward organ donation in Santiago Cuba. Transplantation proceedings, 50(8), 2268-2271. https://doi.org/10.1016/j.transproceed.2018.04.012

Savaşer, S., Mutlu, B., Çağlar, S., Doğan, Z., \& Canbulat, N. (2012). Hemşirelik yüksekokulları öğrencilerinin organ bağışı konusundaki görüşleri (Senior nursing schools students' views on oyrgan donation). İstanbul Üniversitesi Florence Nightingale Hemşirelik Dergisi, 20(1), 1-9 ISSN 1304-4869.

Sayın, Y. (2016). Turkish validity and reliability of organ donation attitude scale. Journal of Clinical Nursing, 25(5-6), 642-55. https://doi.org/10.1111/jocn.12943

Sharma, H. (2019). Assessment of knowledge and attitude of medical students for organ donation. International Journal Forensic Medicine, 1(1), 01-03. https://doi.org/10.33545/27074447.2019.v1.i1a.1 
Soğukpınar, R., Karışan, D., \& Aktamış, H. (2019). 7. ve 8. sınıf öğrencilerinin organ bağışı ve nakli konusundaki bilgi düzeyleri ve görüşlerinin incelenmesi.(Examination of knowledge level and opinions of 7th and 8th grade students on organ donation and transplantation). Kuramsal Eğitimbilim Dergisi, 12(3), 892-914. https://doi.org/10.30831/akukeg.417962

Soysal, A., \& Kaya, N. (2019). Üniversite öğrencilerinin organ bağışı ile ilgili bilgi, tutum ve davranış düzeyleri: Kahramanmaraş Sütçü Imam Universitesi sağlık yönetimi bölümü öğrencileri üzerinde bir araştırma. (Related to organ donation of unıversity students' knowledge, attıtude and behavior levels: A research on the students of the department of health management in Kahramanmaras Sutcu Imam Unıvesıty). Kahramanmaraş Sütçü Imam Üniversitesi Sosyal Bilimler Dergisi, 16(2), 717743. https://doi.org/10.33437/ksusbd.527548.(xxxInTurkish)

Sun, V., Kim, J. Y., Irish, T. L., Borneman, T., Sidhu, R. K., Klein, L., \& Ferrell, B. (2016). Palliative care and spiritual well-being in lung cancer patients and family caregivers. Psychooncology, 25(12), 1448-55. https://doi.org/10.1002/pon.3987

Şantaş, G., \& Şantaş, F. (2018). Türkiye'de organ bağışının mevcut durumu ve organ bağışında stratejik iletişimin önemi (Current situation of organ donation in Turkey and the importance of strategic communication in organ donation.). Süleyman Demirel Universitesi Sağllk Bilimleri Enstitüsü Dergisi, 9(2), 163-168. https://doi.org/10.22312/sdusbed.298160

Şıpkın, S., Şen, B., Akan, S., \& Malak, A. T. (2010). Onsekiz Mart Üniversitesi Tıp Fakültesi, İlahiyat Fakültesi ve Güzel Sanatlar Fakültesi öğretim elemanlarının organ bağışına bakış açılarının incelenmesi (Organ donation and transplantation in Onsekiz Mart Faculty of Medicine, Fine Arts and Theology: Academic Staff's Awareness and Opinions). Adnan Menderes Universitesi Tip Fakültesi Dergisi, 11(1), 19-25

Tarabeih, M., Abu-Rakia, R., Bokek-Cohen, Y., \& Azuri, P. (2020). Christianity, Islam, Judaism, and unwillingness to donate organs post-mortem. Death Studies, 4, 1-8. https://doi.org/10.1080/07481 187.2020.1734114

Tarhan, M., Dalar, L., Yıldırımoğlu, H., Sayar, A., \& Altın, S. (2015). The view of religious officials on organ donation and transplantation in the Zeytinburnu district of Istanbul. Journal of Religion and Health, 54(6), 1975-85. https://doi.org/10.5152/dcbybd.2012.08

Tumin, M., Noh, A., Satar, N. M., Chin-Sieng, C., Soo-Kun, L., Nawi, A., \& Kok-Peng, N. (2013). Organ donation in Muslim countries: The case of Malaysia. Annalls of Transplant, 18, 671-676. https:// doi.org/10.12659/AOT.889194

Türkyılmaz, S., Topbaş, M., Ulusoy, S., Kalyoncu, M., Kılıç, E., \& Çan, G. (2013). Attitudes and behavior regarding organ donation and transplantation on the part of religious officials in the Eastern Black Sea region of Turkey. Transplantation Proceeding, 45(3), 864-8. https://doi.org/10.1016/j. transproceed.2013.02.095

Uzuntarla, Y. (2019). Retrospective investigation of brain death and organ donation cases in a training and research hospital. Journal of the Society of Thoracic Cardio-Vascular Anaesthesia and Intensive Care, 25(4), 264-269. https://doi.org/10.5222/GKDAD.2019.98159

Whisenant, D. P., \& Woodring, B. (2012). Improving attitudes and knowledge towards organ donation among nursing students. International Journal of Nursing Education Scholarship, 13(9), 22. https:// doi.org/10.1515/1548-923X.2404

Yakıt, E., \& Şen, M. A. (2017). Sağlık hizmetleri meslek yüksekokulu öğrencilerinin organ bağışı hakkındaki görüş ve davranışlarının belirlenmesi. (Determınatıon of ıdea and behavıors of organ donations of health services vocational school students). Journal Of Social and Humanities Sciences Research, 4(4), 623-630. https://doi.org/10.26450/jshsr.98(xxxInTurkish)

Yılmaz, M., \& Demirağ, S. (2019). Tıp Fakültesi öğrencilerinin organ bağışı ve nakli ile ilgili bilgi, düşünce ve tutumlarına tıp eğitiminin etkisi. (The Impact of the medical education on students' knowledge, opinion and attitude to organ donation and transplantation). Ankara Medical Journal, 1, 316-324. https://doi.org/10.17098/amj.577001.(xxxInTurkish)

Publisher's Note Springer Nature remains neutral with regard to jurisdictional claims in published maps and institutional affiliations. 